
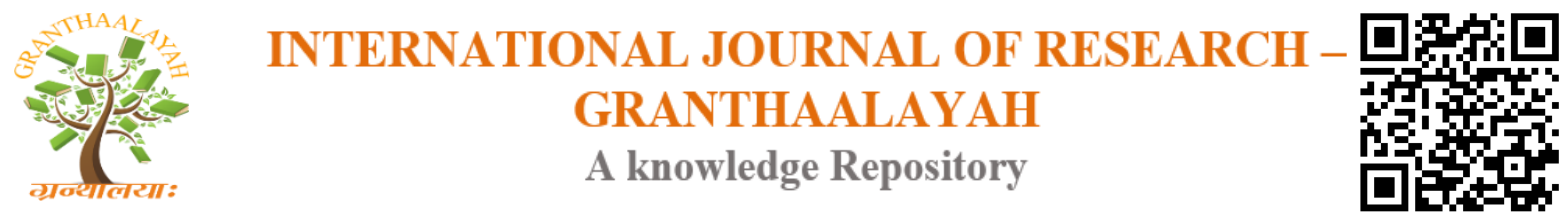

Management

\title{
TO ASSESS THE POSITION OF SMALL MANUFACTURING ENTERPRISES IN ECONOMIC DEVELOPMENT IN ETHOPIA
}

\author{
Shefali Gupta *1 \\ ${ }^{* 1}$ Student, Kurukshetra University, Kurukshetra, India
}

\begin{abstract}
Development of micro and small enterprises holds the attraction of being the most important component of broader economic development and poverty alleviation. They are seen as a key and sustainable generator of employment and income for citizens and tax revenue for the state. They also serve as a bridge between informal economy and the formalized corporate sector in developing countries. Likewise, if they are able to meet the required export quality and standards, for some countries they are a source of foreign exchange earnings. It is also believed that a variant micro and small enterprise sector helps to encourage competition since they are favorable to bring about economic growth.
\end{abstract}

Keywords: Economic Development; Small Manufacturing; Small Enterprises.

Cite This Article: Shefali Gupta. (2019). "TO ASSESS THE POSITION OF SMALL MANUFACTURING ENTERPRISES IN ECONOMIC DEVELOPMENT IN ETHOPIA." International Journal of Research - Granthaalayah, 7(8), 478-488. https://doi.org/10.29121/granthaalayah.v7.i8.2019.702.

\section{Introduction}

UNDP (2012) indicated that considering the development of micro and small enterprises as the key component in industrial policy direction, will contribute to the industrial development in particular and to the economic transformation in general. Micro and small enterprises are profit oriented and generating value-added enterprises contributing to employment and they play a vigorous position in determining the policies and strategies of countries.

Habtamu et al. (2013) discuss that they do serve as means to bring economic transition without using high-tech and sophisticated technology only by using skill and talent of people. Due to this fact, they are preferable to activities of the government towards there eduction of poverty, generation of employment, and generation of income.

Ethiopian Economics Association ((EEA) (2015) also described micro and small enterprises as the natural home of entrepreneurship. Most big businesses in Ethiopia have initially started as micro 
and small enterprises and then have grown to their maturity over along period of time by accumulating capital and business management experiences.

The Ethiopian government has strived to promote micro and small enterprises sector all the way through different laws and regulations and also support programs. The government of Ethiopia has taken actions to boost the operation of micro and small enterprises.

Ministry of Urban Development and Construction of Ethiopia (MUDC, 2013) discussed that the first proclamation regarding licensing, supervision of micro financing institution No. 40/2004 was enacted in 2004. The Federal and Regional Micro and Small Enterprises Strategy was prepared in 2004 and this Federal and Regional Micro and Small Enterprises Development Agency (FeMSEDA) was established by the regulation No. of 33/2005. Following this to promote the growth and development of these enterprises institutional platforms were created to play their decisive role in national growth and transformation process.

MoFED (2010) witnessed that in Ethiopia, micro and small enterprises have contributed in generating employment opportunities, in mitigating poverty, in creating entrepreneurship and in the development of national development.

The government has currently given due attention to micro and small enterprise sector development and manufacturing sector development in particular. The two consecutive plans: first and second growth and transformation plans (GTP) for the periods 2011-2015 and 2016-2020 respectively has stressed the call for providing support to micro and small enterprises both at federal and regional states level.

According to MoFED (2015) report, the economic growth (GDP at a constant basic price) for 2014/15 was 10.2 per cent. Out of this, the report also shows that the share of the industrial sector is only 15 percent while the shares of agriculture and service sectors are 39 percent and 46 percent, respectively. The annual average growth rates of these major sectors i.e. agriculture, industry, and services are 6.4 percent, 21.7 percent and 10.2 percent, respectively. The poverty level of the country also declined from 34.6 percent in 2009 to 22 percent in 2015 . Regarding the number of enterprises established during last 8 years of the period, the total number of enterprises before the year of 2006 was 40,047 and increased to 407,269 in 2013/14 and it shows that the number of establishments increased by 9.83 percent.

According to FeMSEDA (2015) reported in 2015 that out of 46,617 small manufacturing enterprises, only 707 (15 per cent) enterprises were operating in Oromia regional state.

Despite, the roles of micro and small enterprises playing in there eduction of poverty, the creation of employment, the creation of entrepreneurship and development of Ethiopia, many challenges, whose harshness differ from region to region and from city to city facing the sector.

In spite of the potential contributions of small and medium enterprises to accelerate economic growth especially in developing countries including Ethiopia a number of bottlenecks affect their capability to put into practice. 
MoFED (2015) report identified that in Ethiopia the most prevalent constraints include lack of adequate finance, lack of managerial skills or managerial know-how, lack of support services, lack of training services and others. Besides these constraints, in the study area problems of lack of good governance, lack of working premises, and instability of local market situation and the like are other problems this study came up with. The focus of this study is however, limited to small manufacturing enterprises operating in the study period in urban areas of Oromia Regional State of Ethiopia. However, most of the time, enterprises engaged in producing or assembling physical products are categorized under manufacturing sector.

The International Standard Industrial Classification (CSA 2003) defines manufacturing activity as the alteration of materials or components into new products physically or chemically by using power-driven machine or by human power. Assembling of sections of manufactured materials is also considered as manufacturing. Accordingly, small manufacturing enterpriseswhich is the theme of this study investigates the small manufacturing enterprises producing products by using manpower or power driven machines. Enterprises involved in the following business types are categorized under manufacturing sector in the study area.

\section{Literature Review}

Regarding the contribution of micro and small enterprises, two polarized views emerged: i.e. the pro and the contra.

Agyapong (2010) and Staley \& Morse (1965) classified the role and contribution of MSEs in economic growth and poverty reduction into pro and contra arguments. Their works are often divided as the Classical and Modern theories on micro and small enterprises' development. The contra argument forecasts that benefits of micro and small enterprises will weaken over time and large enterprises will ultimately prevail in the economic development registered by the raise in income.

Biggs (2002) cited in Tegegne and Meheret (2010) put under question the contribution of micro and small enterprises to reduce the occurrence of a high level of poverty in most developing economies through the creation of employments, generation of income and multiplier effects on other sectors of the economy. Whilst, the pro argument outlook from experiences of many countries showing the 'contra' arguments seem to get fewer supports from the World Bank and many international aid agencies.

Tulus (2006) pointed out that the World Bank gives three core arguments in supporting MSEs in developing countries, which in line with the arguments of the 'modern' (pro) paradigm on the importance of micro and small enterprises in the economy. First, the existence of micro and small enterprises improves competition and entrepreneurship. Consequently, it is advantageous to improve the efficiency of the economy, aggregate productivity growth, and innovation. The second argument is that micro and small enterprises are generally more productive than large enterprises, but failures of financial markets and institutions to create a conducive environment to micro and small enterprises impede the proper development of these enterprises. 
The last argument is that micro and small enterprises expansion boosts employment more than large enterprises growth because micro and small enterprises are more labor intensive. In developing countries, the direct government supports for MSEs help them to make use of social benefits from their high competition and to boost economic growth and development.

The above arguments do not mean, however, that large enterprises are not important, or micro and small enterprises can fully substitute the role of large enterprises in the economy. Even, from many authors about this pro-MSE policy of the World Bank, there are skeptical views.

Snodgrass \& Winkler (2004) in supporting the positive contribution of micro and small enterprises in economic development explain that the growth of micro and small enterprises boosts employment more than the growths of large firms because micro and small enterprises are more labour intensive.

Beck \& et al. (2004) also discuss that subsidizing micro and small enterprises may help to reduce poverty. However, the contra arguments have questioned the efficacy of micro and small enterprises in promoting growth and reducing poverty. They argue that large enterprises may take advantage of economies of scale and can easily make use of the fixed asset to improve productivity. Little (1987) discusses that the smallest enterprises are the less efficient. But, it is also mentioned that there are some substantiations that as compared to medium and enterprises, both small and large enterprises are relatively inefficient.

Acs, et al. (1990) also discuss that for large firms the contribution ofinnovations to productivity often takes time may have more resources to adapt and implement them whereas small firms bring innovation to the marketplaces.

Biggs and Shah (2005) clearly noted that MSEs do not take a comparative advantage in the innovation of new technologies or in creating potential entrepreneurs. Furthermore, the net employment generation of these enterprises is not necessarily high and is frequently lower than for larger enterprises. The larger share of employment generated in explicably inherited in large enterprises.

Hallberg (2001) in supporting the above view noted that larger employers deliver better job opportunities in terms of benefits, wages, job security and opportunities for skill enhancement.

In general, most of the studies in both developing and developed countries argue that there is a positive correlation between economic growth and micro and small manufacturing enterprises. Micro and small enterprises contribute to economic development in various ways. They are increasingly being recognized as productive drivers of economic growth and a major source of job creation.

Hussmanns and Mehran (2005) discuss that micro and small enterprise sector creates employment opportunities, encourage the development of indigenous entrepreneurship, enhance regional economic balance through industrial dispersal and generally promote effective resource utilization. MSEs contribute to the economy of developing countries in various ways. For developing economies, small and medium enterprises are gradually being recognized as productive drivers of 
economic growth and a major source of job creation. The global trend of larger enterprises to reorganize, downsize and outsource with the increase in franchising and self-employment increases the number of small and medium enterprises.

Osotimehin, et al (2012) noted micro and small scale businesses as catalysts in the socio-economic development of any country. Micro and small enterprises are authentic vehicles for the attainment of national macroeconomic objectives through the generation of employment opportunities at the low cost of investment and improvement of apprenticeship training.

The catalytic roles of small businesses have been exhibited in many countries of the world like India, Malaysia, South Korea, and Zambia. They contribute considerably to the export earning, Gross Domestic production (GDP), and job opportunities of these countries. Not only in the above countries, in most nations of the world, small-scale enterprises have been broadly accredited as the launch pad for sustainable economic development.

Mensah (2004) indicated that in Ghana 90 per cent of registered companies are micro, small and medium enterprises. They have been recognized as the catalysts for the country's economic growth since these enterprises are themain source of income and employment opportunities.

Harvie (2004) in his review of micro and small enterprises sector contributions to the growth and development of East Asian economies pointed out that the sectors' increasing importance to the region's recovery of sustained economic growth, employment, trade, investment, and the development of globally competitive economies.

Miah (2007) explained that they provide 71 per centin Sri Lanka and 87 percent of GDP in Bangladesh. MSEs' share of total national production was 54 percent in Bangladesh and 40 per cent in Sri Lanka. In Bangladesh, the various categories of medium enterprises together contribute between 80 per cent to 85 per cent of industrial employment and 23 per cent of total civilian employment. Amir (2012) stated that, in Nepal, more than 80 per cent of the national value addition in the manufacturing sector comes from medium enterprises, the share possibly being even higher in the non-manufacturing sectors. Medium enterprises employ 98per cent of the non-agricultural labour force and attract around 40per cent of all industrial investment in Nepal in1999-2000. In Sri Lanka within the manufacturing sector medium enterprises account for about 96per cent of industrial units, and 36per cent of industrial employment. As India Ministry of Micro, Small and Medium Enterprises (2013-14) report cited in Amir indicated, micro, small and medium enterprises (MSME) sector has emerged as a highly vibrant and dynamic sector of the Indian economy over the last five decades. Medium, small and micro enterprises (MSMEs) not only play avital role in offering bulk job opportunities at comparatively lower capital cost than large industries but also help in the industrialization of rural areas and aiming at reducing regional disparities, guaranteeing more equitable distribution of national income and wealth. Micro, Small and Medium Enterprises are complementary to large industries as an auxiliary unit contributes a lot to the socioeconomic development of the country. According to this report, for six consecutive years (2006/07-2011/12), the average percentage share of MSMEs from GDP was 7.54per cent and the total employment in the year 2012/13 was 1061.52 lakh (106,152,000).Amir also explained that, in India, medium enterprises account for some 95 per cent of all industrial units, 40 per cent of industrial output and 35per cent of national exports. 
SMEDA (2006) discusses that in Pakistan, the MEs employing approximately 70 per cent of total employment and absorbing more than 80 per cent of non-farm employment. MEs contribute over 30 per cent to GDP, 25 per cent of export earnings besides sharing 35per cent in manufacturing value addition.

Czinkota et al. (1983) cited in Chosnie et al. (2014), argue thatmicro and small enterprises are weak in Africa because of small local markets, entry of many firms into their markets with sometimes better products, weak regional amalgamation, and very complicated business circumstances. This condition reflected in terms of burdensome official procedures, poor infrastructure, uninsured legal systems, and uninviting tax regimes or hard business environments. That is, many enterprises stay small and use simple technology that does not require the high use of national infrastructure. These are some of the possible facts that encumber them from becoming competitive in the market.

ILO (2002) explained Micro and small enterprises have a significant contribution in creating employment opportunities for the poor in urban areas. Accordingly, this sector generates about 48 per cent of the aggregate employment in North Africa, about 51 per cent in Latin America, 65 per cent in Asia and 72 per cent in 15 Sub Saharan Africa. Todaro (2000) cited in Endalsasa (2012) stated that the sector of micro and small enterprises is a major source of urban employment in most Asian countries. Among individual countries for which statistics are available; the figure reaches 50 per cent in India, 60 per cent in Pakistan, 45 per cent in Indonesia, 35 per cent in Malaysia. In the case of Latin American countries, it reaches 69per cent in Paraguay, 61per cent in Bolivia, 56 per cent in Brazil and 55 per cent in Argentina. World Bank (2008) explained that most women are not found engaged in outdoor employment opportunities in Ethiopia. They are deprived of higher decision-making positions, equality of inheritances, decent works and other economic activities in developing countries in general and in Ethiopia in particular. As a result, since Micro and small enterprises are started with low financial capital and credit and have the capacity to absorb huge low-level income populations, they can help women to have easy access to employment and be the owner of the enterprises.

Seyum (2015) summarizes that different study shows that micro and small enterprises are imperative means in poverty reduction through the creation of employment opportunities and source of income for low-income citizens with limited opportunities. They do have the capacity to increase the level of income of individuals and to improve the living standards of the larger poor because they need low startup capital and their potential to absorb the huge proportion of the uneducated or the low educated work force, which is the reality in the poor countries like Ethiopia. Hafez (2013) noted out that in Egypt, for example, about 99per cent of the enterprises are SMEs and they created 77 per cent of job opportunities. The global trend of larger enterprises to reorganize, downsize and outsource coexist with the increase in franchising and self-employment increases the number of SMEs.

Harabi (2005) on the other hand, reported that micro- and small enterprises in Uganda play a significant role as they employ 90 percent of the active non-farming population. Approximately one-third of the Ugandan population is engaged in entrepreneurial activities, particularly micro and small enterprises, and only a few medium and large enterprises exist in Ugandan business sector. Several Ugandan enterprises absorb only less than 50 paid man powers, and the greater part 
has employed only less than 20 workers. Micro and small enterprises are not growing. The industrial sector, which is dominated by micro and small enterprises, still contributes less than 20 percent to the GDP and has not been performing impressively.

Osotimehin et al. (2012) also noted that in Nigeria, SMEs have not performed creditably well, and have not played expected a significant role in economic growth. SMEs have been seen not to control training of trainees but, as a result, to speed up the journey to job creation and poverty reduction to encourage Nigerian economic growth. In reality, in currently, their contributions to export exchange earnings is insignificant, as compared to other countries, which entails that there should be extra, thoughspecific to the country reason or factors thwart against the growth of small and medium enterprises in Nigeria.

Sveinung et al. (2011) try to identify the most important obstacles to SME growth in Sub-Saharan Africa. In, Sub-Saharan African countries, SMEs are rigorously hindered by an imperceptibly developed business environment. Red-tape and bottleneck problems like corruption, multifaceted regulations of entry etc. offer few inducements to become or remain in the formal sector of the economy. Consequently, in most of these countries, a large amount of small and medium enterprises is not taking part in the formal economy. Being an informal enterprise, access to a source of debt finance, accessing new markets areas and public services is strictly hindered. There is also a strong association between business environment and small and medium enterprise growth. The better the business environment, the more SMEs will be established. Ekpnyong \& Nyong (1992), Okpara,( 2011 ) and Fatai (2011) have also identified factors like limited access to financial support, weak management, corruption, poor skills of management, limited access toinfrastructure, inadequate profits and low demand for products and services.

The roles of small-scale enterprises to the national economy have also been acknowledged in many developed economies countries of the world.

Baumol (2007) quite frankly pointed out that, economic growth of the past two centuries, in which entrepreneurs possibly played a decisive role, can be expected to have a better real per-capita income of USA by a surprising 2,000 per cent or even more. Undoubtedly, the presence of the Microsoft, Apples and the Disney together helped to build the U.S economy.

Fan (2003) and Ariyo (2006) cited in Essien (2014) discuss small scale enterprises contribute over 55 per cent of GDP and over 65 per cent of total employment in high-income countries. They also account for over 60 per cent of GDP and over 70 per cent of total employment in low-income countries, while they contribute over 70 per cent of GDP and 95 per cent of total employment in middle-income countries.

Hillary (1991) discusses that they provide employment opportunities for millions of individuals; their work is strongly customer-orientated; they are sources of entrepreneurship and innovation; they enhance competition and they are the seed for enterprises of the future. The worldwide contribution of SMEs to economic development is significant.

Wilson (1998) explains that in the developed countries, small and medium enterprises (SMEs) are also considered as an important employment provider. In the UK, SMEs generate over a quarter 
of GDP. They generate 44 per cent of employment. The trends are all upward. The share of employment provided by SMEs is also mentionable. The Sector is also a vital part of all the European Union economies, accounting for 65 per cent of EU turnover. They dominate many service sectors, particularly hotels, catering, retailing and wholesaling and construction.

UN-Habitat (2013) reported that, across the EU, MEs generate 66 per cent of employment. Particularly, in Italy, the proportion is 79 per cent, in France, it is 63per cent, in Germany it is 60 per cent and in the UK, it is 61.5per cent. In the USA, it is estimated that SMEs now generate 50 per cent of GDP and in Japan, they provide 81per cent employment. Between 2009 and 2010, due to financial crises, the SME sector bounced back with an overall 4.3per cent growth in the value added produced by European SMEs, while employment in SMEs stagnated. However, the report also discusses that the 20 million European SMEs play an important role in the European economy. These are mostly micro-enterprises and in 2012 employed approximately 86.8 million people. This represents 66.5 per cent of all European jobs for that year. Micro-enterprises provide just under a third of that total employment figure. The small and medium enterprises sector in general delivered 57.6per cent of the gross value added generated by non-financial economy of private sectors in Europe for the period of 2012 and for over $€ 3.4$ trillion value added against a total value added produced by the private, nonfinancial sectors of approximately $€ 5.9$ trillion. A substantial share of European small and medium enterprises in 2012 was to the services and manufacturing sectors. Both service and manufacturing sectors together created 74 million job opportunities for citizens and produced $€ 2.9$ trillion of value added, with 85 per cent of all European SMEs working in these two sectors

\section{Highlights of the Current Economic Conditions of Ethiopia}

The Ethiopian economy is mainly dependent upon agriculture and therefore the economic policy of the country is tilted towards agricultural development. The current economic policy is Agricultural Development Led Industrialization (ADLI). Also, as the case for other developing countries, Ethiopia's exports suffer from deteriorating terms of trade and incomeinelastic demand. But, the share of agriculture from GDP of the country is now declining and has become less than that of the service sector. As reported by MoFED (2015), in 2015, as shown in Fig 3.3, below, the shares of the major sectors, out of the total GDP were about 39 per cent, 15 per cent and 46 per cent, respectively.

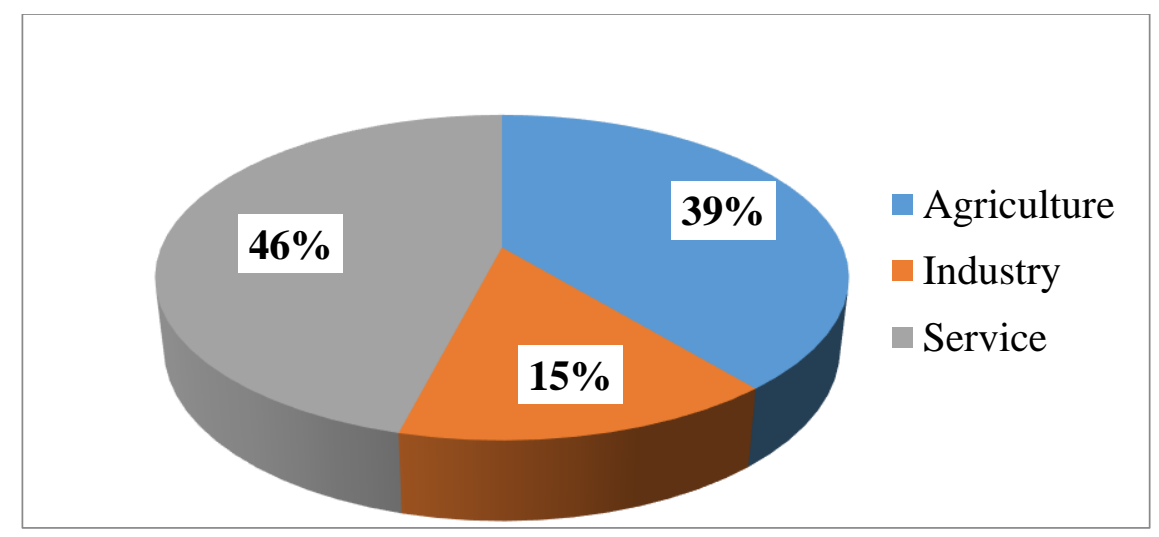

Figure 3: Share of Major Economic Sectors in GDP

Source: - Computed from MoFED Report (2015) 
According to this report, the economic growth (GDP at a constant basic price) for 2014/15 was 10.2 per cent.

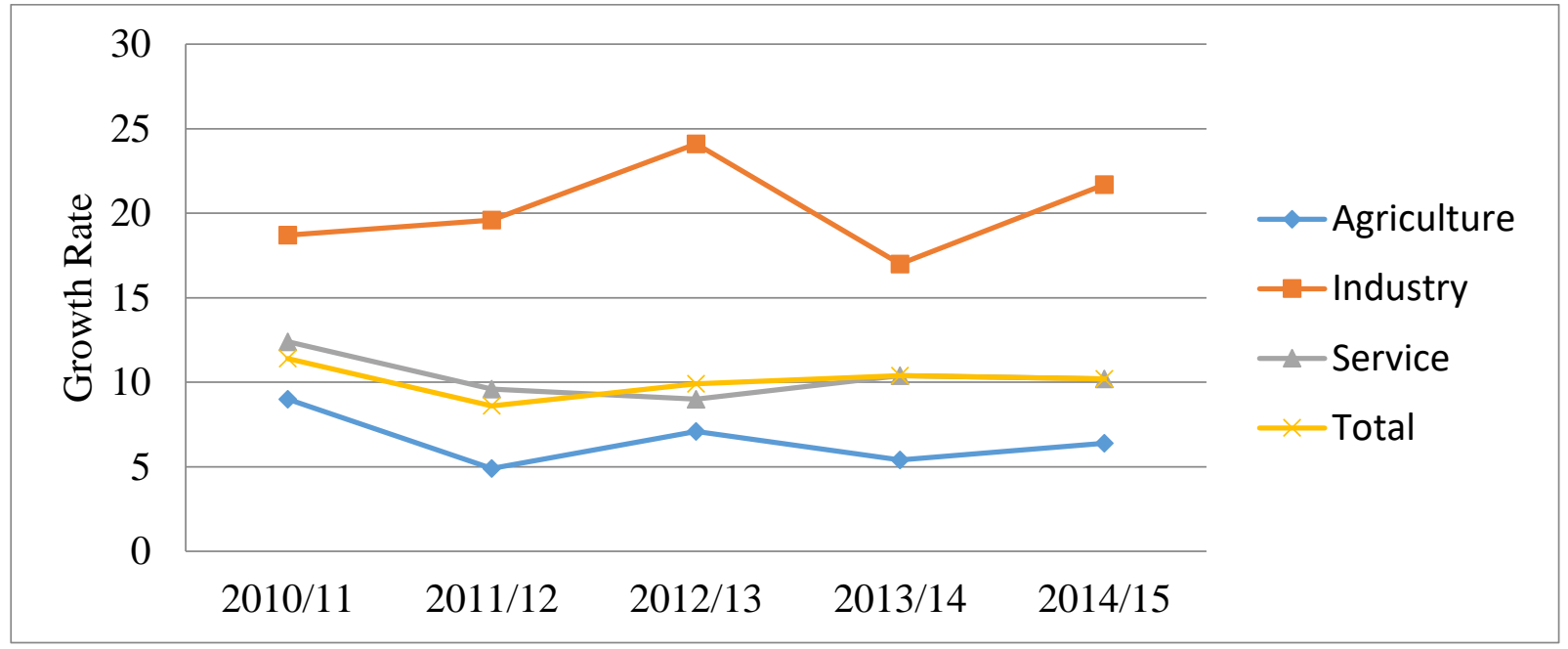

Figure 3: Annual Growth Rate of Major Economic Sectors in\%

Source: Compiled from MoFEDReport, 2015

As indicated in Table 3.1, over the last twelve consecutive years (i.e. during 2003/04-2014/15), the economy has registered growth. Accordingly, in this period the annual average growth rate of GDP was 10.8 per cent. The agriculture, industry and service sectors' annual average growth were 8.8 per cent, 14.4 per cent and 11 per cent respectively. The maximum growth of industrial sector was registered in 2012/13 which is 24.1 per cent and declined to 21.7 per centin the final year of the plan period. But the growth rate of agriculture sector was declined from 9 per cent at initial year of the five years (GTP) period to 6.4 per cent in 2014/15.

Table 3: Growth Rate of GDP by Major Economic Sectors at Constant Price in per cent

\begin{tabular}{|c|c|c|c|c|c|c|c|}
\hline \multirow{2}{*}{ Sector } & \multicolumn{7}{|c|}{ Years } \\
\hline & $\underset{\bar{D}}{\stackrel{1}{\sigma}}$ & 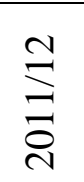 & $\frac{m}{\stackrel{n}{0}}$ & $\underset{戸}{\Xi}$ & $\stackrel{n}{\underset{Ð}{\ominus}}$ & 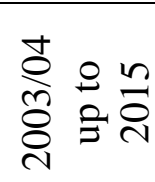 & 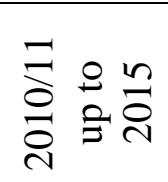 \\
\hline Agriculture & 9 & 4.9 & 7.1 & 5.4 & 6.4 & 8.8 & 6.6 \\
\hline Industry & 18.7 & 19.6 & 24.1 & 17.0 & 21.7 & 14.4 & 20.2 \\
\hline Service & 12.4 & 9.6 & 9.0 & 10.4 & 10.2 & 11.9 & 10.8 \\
\hline Total & 11.4 & 8.6 & 9.9 & 10.4 & 10.2 & 10.8 & 10.1 \\
\hline
\end{tabular}

Source: Compiled from MoFEDReport, 2015

Based on paid up capital or capital investment, the old definition was given in 1998 by Ministry of Trade and Industry (MoIT, 1997). According to this definition, micro enterprises were those enterprises which have a in the last five years (2010/11 -2014/15), Growth and Transformation Plan (GTP I) implementation period, the economy has registered the GDP annual average growth rate of 10.1 per cent. Agriculture, industry, and service sectors have 6.6 per cent 20.2 per cent, and 10.8 per cent annual average growth rates respectively. Also, Ministry of Finance and Economic 
Development of Ethiopia MoFED (2015) reported that the poverty level decreased from 34.6 per cent in 2003/04 to 22 per cent in the final year of the first GTP implementation period.

The problem of employment generation in the Ethiopia stays one of the long-term development objectives. It requires a lot to do along with the structure and high population growth rate of the country and the inherent characteristics of the economy. Census undertook in 2008 estimated that in urban areas of Ethiopia unemployment rate was estimated to be about 20.6 per cent as compared to only 2.6 per cent in rural areas and to give 5 per cent for the nation as a whole. This shows that urban areas of Ethiopia are characterized by a very high rate of unemployment.

\section{Conclusions}

Among other criteria, the definition of micro and small enterprises of Ethiopia is based on number of human power employed and the capital assets of the enterprises. However, there is a substantial difference between the definition by Federal Micro and Small Enterprise Development Agency of Ethiopia (FeMSEDA) and Central Statistics Agency (CSA) of the country. FeMSEDA defines micro enterprises as those enterprises categorized by the employment size of 3 to 5 persons and small enterprises with the employment size of 6 to 30 persons. On the other hand, CSA categorized enterprises under two categories. These categories of enterprises are small-scale manufacturing enterprises and medium enterprises. Small scale enterprises are those enterprises having up to 10 employees, and medium enterprises are those enterprises having more than 10 workers. These two definitions given by the two government institutions are different and are more often mixed up.

Therefore, it is difficult to compare various research findings based on the reports from these governmental institutions. But this sector is a priority area for the government and also policies are often formulated to create conducive working environment. Even, the contribution of this micro and small enterprise sector does not appear in the GDP since the national macroeconomic report of the country is based on the CSA's report which does not distinguish between micro and small enterprises and it incorporates only the manufacturing sector. There should be a consistency between the two definitions of the two government institutions.

The results of the secondary data analysis of this study show that, among various regions in Ethiopia, there is a wide gap of distribution of micro and small enterprises. This has to attract the government attention in order to reduce income inequality among citizens and regional states.

Some of the findings of this study are supporting findings of different studies related to enterprise growth. In line with some empirical studies, the size of urban manufacturing enterprises in the study area significantly affects growth of enterprise. But, age of the enterprise has no strong impact. Therefore, enterprises need to pay attention to the size of employment during start-up. Among other business practices included in the study, only market area affects the enterprise growth. Enterprises with large market areas in the study area have shown growth in the study period than others. So, in order to grow these enterprises need to seek different mechanisms through which they expand their market for their products. 


\section{References}

[1] Acs, Z.J. \& Audrestch, D.B. (1990). Innovation and Small Firms, Cambridge: MIT Press.

[2] Agyapong, D. (2010). Micro, Small and Medium Enterprises' Activities, Income Level and Poverty Reduction in Ghana - A Synthesis of Related Literature. International Journal of Business and Management, 5(3): 196-205.

[3] Almus, M. \& Nerlinger, E. A. (1999). Growth of New Technology-Based Firms: Which Factors Matter? Journal of Small Business Economics. 13(2):141-154

[4] Amir (2012). Critical Analysis of Micro Enterprise Policy Development in Developing Countries: A Case of Bangladesh. Brunel Business School (BBS). Brunel University, London. A Thesis Submitted for the Degree of Doctor of Philosophy

[5] Anderson, Dennis \& Carrier, L. (1994). Small Industry in Developing Countries: Some Issues. World Bank Staff king Paper 518. Washington, D.C.

[6] Bridge, S., O’Neill, K., \& Martin, F. (2009) Understanding enterprise, entrepreneurship and smallbusiness, Basingstoke: Palgrave McMillan.

[7] Buvinic, M. (1993). Promoting Women's Enterprises: What Africa Can Learn from Latin America: Intermediate Technology Publications. SRP, Exeter, UK. Cambridge, Mass.: MIT Press Cambridge, Mass.: MIT Press.

[8] Hallberg, K. (2001). A Market-Oriented Strategy for Small and Medium-scale Enterprises. Discussion Paper No. 48. International Finance Corporation. Washington DC, USA.

[9] Harabi N. (2005) Determinants of Firm Growth: An Empirical Analysis from Morocco University of Applied Sciences, Northwestern Switzerland, July 2005

[10] Harabi, N. (2003). Determinants of Firm Growth: An Empirical Analysis from Morocco: Solothurn University of Applied Science: Northwestern, Switzerland.

*Corresponding author.

E-mail address: shefg2507@ gmail.com 